\title{
Reimagining the purpose of VET - Expanding the capability to aspire in South African Further Education and Training students
}

\author{
Lesley Powell
}

School of Education, University of Nottingham, UK

\begin{abstract}
This paper applies the capabilities approach to the broader debate of the role of vocational education and training (VET) in poverty alleviation. The capabilities approach provides an approach for conceptualising and evaluating VET which differs in orientation from dominant productivist conceptions. It does so by shifting the focus from economic development to human development. By placing the well-being of VET students at the centre of our concern it shifts the lens from income generation and with it employability to a lens on capability expansion which includes but is not limited to the capability to work. The paper is based on interviews with 20 South African Further Education and Training (FET) college students. The central argument is that VET has an important role to play in poverty alleviation, but only if located in a multi-dimensional view of poverty which understands poverty as capability deprivation across multiple human functionings. In this broader notion of poverty, the role that VET plays includes training for employability, but also includes the expansion of other important capabilities such as, and in the voice of a FET student interviewed in this study, 'the ability to dream', or in the language of the capabilities approach, the capability to aspire.
\end{abstract}

\section{Keywords}

Vocational Education and Training; Capability Approach; Capabilities Approach; Further Education and Training; South Africa; Capability to Aspire 
Forthcoming in the International Journal Of Educational Development, Vol. 32 (5).

\section{Introduction}

In an essay providing hints for Vocational Education planners published in this journal in 1991, Psacharopoulos argues against vocational education and training (VET) as a viable policy option for social and economic development in Africa (Psacharopoulos, 1991). Supporting the argument made almost three decades earlier by Foster (1965a,b), he provides the key reason for this as being the divide that exists between the aspirations of policy makers for increased participation in VET and the aspirations of young people for academic rather than vocational education (Psacharopoulos, 1991; Foster, 1965a,b). The argument being that young people avoid VET in favour of an academic education, as they regard VET as preparing them for unemployment or for work that is repetitive, boring and underpaid (Psacharopoulos, 1991; Oketch, 2007).

Sociological concerns regarding student aspirations together with concerns about the rates of return of investments in VET (Psacharopoulos, 1985) resulted in a dilemma in Africa over whether to invest in VET or in general education (Oketch, 2007). The outcome was a decline in donor and political commitment to VET. Basic and primary education rather than vocational education were seen as the route to poverty reduction and economic growth, culminating in the non-inclusion of VET in the Millennium Development Goals which emphasised Education For All (EFA) through basic education (King, 2009a,b; Palmer, 2007).

Notwithstanding the strong views of Psacharopoulos (1991) and the decline in policy and donor support for VET over the past half century, the last decade has seen VET moving to the centre of policies that aim to solve unemployment and reduce poverty in Africa (see McGrath, 2012). This new wave, as it has begun to be viewed, of interest and optimism in VET in Africa is underpinned by a shared paradigm. Most notable in this shared paradigm is the assumption that education and training holds the key to economic competitiveness and the answer to addressing social inequities and increasing levels of unemployment, particularly youth unemployment. In these policy frameworks VET has a dual role to play. On the one hand, it is to contribute to economic development by providing the skills required to compete in challenging and changing global and national economic contexts. Simultaneously, and on the other hand, it is to contribute to poverty alleviation and social justice by widening participation in education and training targeted at employability and most particularly at 
Forthcoming in the International Journal Of Educational Development, Vol. 32 (5).

the employability of those communities most affected by unemployment and poverty.

Recent policy aspirations have renewed hopes in VET to contribute to social and economic development in Africa (McGrath, 2011). The key question is whether VET and the policy frameworks within which it is constituted can rise to the challenge. According to McGrath (2011), to do so must include addressing concerns raised about VET in Africa over the past half century. This is particularly so as many of these new policies stipulate goals that appear to "mirror some of the debates of the late 1960s" through their emphasis on VET as an instrument for addressing unemploy-ment and skills shortages in the public and private sectors (McGrath, 2011, p. 38). The renewed interest in vocational education has prompted increased debate and questioning about the role that VET should and can play in developing contexts and the policy frameworks that best enable success. Cutting across these debates are the questions asked by Palmer in 2007, "Training for what?" and "what kind of training for whom?" (Palmer, 2007, p. 405) and more recently by King (2011), "now that TVET has the floor - what is the storyline?". There has been serious grappling with these questions over the past few years (see Winch, 2000; Lewis, 2009) and increasingly so as we progress towards the EFA Global Monitoring Report, 2012 and the Third International Congress on TVET which is to be held in Shanghai in 2012.

A key contribution is made by McGrath (2011) who highlights the contradiction that exists between the "current policy trajectory and the research orthodoxy" (2011, p. 35). Drawing on literatures about VET in Africa, he demonstrates that the dominant conception is that VET is "neither an efficient nor an effective policy response to Africa's educational development challenges" (McGrath, 2011, p. 35). He warns that the new wave of optimism which sees VET as a solution to Africa's development challenges is certain to suffer if the concerns raised over the past half century are not adequately dealt with (McGrath, 2011). His central argument is that the success of this new wave is dependent on a reconceptualisation of the role and purpose of VET - there is, as he states, a need to "reimagine the purpose" of vocational education in Africa (McGrath, 2011, p. 36). McGrath (2012) takes the argument further by suggesting that this 'reimag[ing]' needs to take place within revised developmental paradigms which, and to various degrees, oppose and supersede the 'productivist' frameworks in which VET is currently located. The focus of these 'productivist' frameworks is the development of human 
Forthcoming in the International Journal Of Educational Development, Vol. 32 (5).

capital for economic advancement and employability as a solution for unemployment (McGrath, 2011).

It is here, in this 'reimagin[ing of] the purpose' of VET, that this paper is located. Although the empirical focus is the South African context, specifically the South African public Further Education and Training (FET) colleges, the paper is situated within the broader debate on the role that VET plays and can play in developing contexts and specifically, the role that VET plays in poverty alleviation. The paper brings two aspects to the debate. First is the application of the capabilities approach ${ }^{1}$. Embodied in the Human Development Index, the capabilities approach allows for a paradigm shift from a focus on economic growth and national income to a focus on human well-being (Tikly and Barrett, 2011). While neither Amartya Sen nor Martha Nussbaum seek to link the capabilities approach directly to educational processes and out-comes an emerging body of literature has developed which applies the capabilities approach to the theorising of schooling and higher education. This paper draws from this body of literature and provides an exploratory attempt at applying the framework and concepts of the capabilities approach to the study of VET.

The second, and in line with the emphasis on agency in the capabilities approach, is that it brings to the discussion the voice and perspectives of students. Much of the debate about the role and location of VET in Africa has been between academics, donors and policy makers with learners and the perspective of learners largely excluded. When student perspectives have been included it has generally been through the findings of quantitative studies such as that undertaken by Foster $(1965 \mathrm{a}, \mathrm{b})$ in his study of learner aspirations in Ghana.

This is similarly so in South Africa. An exception is the technical college situational analyses undertaken in the period 1998-2004 which included in the institutional studies a small number of group interviews with students. The student interviews were only marginally reported in the final reports and then only to highlight concerns or complaints with the then technical colleges (Fisher et al., 1998, 1999; Jaff, 2000a,b,c,d). Another exception is the letters received by the Human Sciences Research Council (HSRC)

\footnotetext{
1 The capabilities approach is also called the human development approach and the capability approach. In line with Nussbaum (2011), the term capabilities is used in this paper to denote the multidimensional capabilities required to live a flourishing life.
} 
Forthcoming in the International Journal Of Educational Development, Vol. 32 (5).

during a study surveying student destinations (Cosser et al., 2003). A few students took it upon themselves to include in their returned survey a letter providing further explanation of their experience of FET (then technical colleges). "I am writing you this letter", writes one of these students, "because I feel there's a few things you need to know! (That I would like to share with you)" (Cosser, 2003, p. 102). And another, "please help us to be heard because we are just whispering and searching in the dark" (Cosser, 2003, p. 90). The letters submitted by these students were not a designed aspect of the project, but an unintended consequence thereof. Nonetheless, they express poignantly the deep desire expressed by the learners 'to be heard' which the HSRC acknowledged in a chapter of the book devoted to the study. Another and more recent exception is the City and Guilds (2011) study which explores the attitudes of young people in South Africa, the Netherlands and England towards VET. There is, however, and as argued by Cook-Sather (2002), "something fundamentally amiss about building and rebuilding an entire system without consulting at any point those it is ostensibly designed to serve" (2002, p. 3).

The central question of the paper relates to the role that VET plays and can play in the lives of students from low socio-economic communities. It does so by drawing on the perspective of a sample of students with the aim of determining the benefit of FET (VET) for their lives. It is necessary at the outset to signal a caveat. The paper draws from the first of two phases of my doctoral study in which the emphasis is on determining the capabilities that students value for their lives and the extent to which FET has either enabled the expansion or the contraction of these capabilities. The first phase focussed on the reasons for enrolling at the college and the college experience. The second phase is focussed on tracking the students, over $75 \%$ of whom were scheduled to have completed their final examination. In keeping with much of the education capabilities tradition, this paper is based on in-depth interviews undertaken with a relatively small sample of 20 students located at one South African FET college. In light of this, it should be noted that while the paper provides an argument for re-conceptualising the role of VET in poverty alleviation, it does not provide and nor does it aim to provide a plan for practice or policy. Rather, and within the context of this new wave of optimism and interest in VET in Africa, it aims to broaden the debate and open discussion in this quest to 'reimagine the purpose' of VET. 
Forthcoming in the International Journal Of Educational Development, Vol. 32 (5).

Before discussing the role that VET can play in poverty alleviation, we move to the context of this study: South African FET colleges and the socio-economic context within which they are located.

\subsection{The South African FET colleges}

South Africa's skills development approach is well discussed by Akojee et al. (2007), Allais (2003), Kraak (2007), Lewis (2009), McGrath et al. (2004), McGrath and Akoojee $(2007,2009)$ and many others. So too is the development and the role of the South African public FET colleges (see Fisher et al., 2003; McGrath, 2000, 2004, 2010). As such, only a brief summary is provided here.

Existing at the cross roads between compulsory education, higher education and the world of work, South Africa's public FET colleges are to respond to the skill needs of the South African economy. Simultaneously, they are to respond to the social disparities of apartheid by providing disadvantaged communities with access to high quality and relevant education and training that provides the skills and attitudes required for employability, including - within the context of insufficient jobs in the formal economy - training for entrepreneurship (Badroodien and Kraak, 2006) and for the informal economy (King and McGrath, 1999). Colleges also have an important role to play in providing second chance and non-traditional access routes to higher education (McGrath et al., 2010).

In the context of growing unemployment, which for the general population wavered around 25\% for the period 2005-2009 (McGrath et al., 2010), the official ambition is to expand participation in public FET colleges to $20 \%$ of unemployed youth and to a total of one million students by 2014 (Department of Education, 2008). This is particularly so for youth unemployment which has reached staggering levels of close to three quarters of South African youth (Bhorat, 2006). Unemployment and underemployment imitate the contours of apartheid's unequal configuration with the highest percentages being African, female and rural. Within this context, the remit is for colleges to address the mismatch in the South African labour market between high levels of unemployment (particularly youth unemployment) existing at the same time as critical skill shortages at the intermediate to higher skill levels (Bhorat, 2008; Daniels, 2007).

In response to these mandates the colleges serve a wide range of students (McGrath, 2010). They provide pre-service training to young students, up- 
Forthcoming in the International Journal Of Educational Development, Vol. 32 (5).

skilling and retraining for adults and also support adult students through literacy and numeracy training (McGrath, 2010). Currently half a million students per year are enrolled in the public FET colleges ${ }^{2}$. How do these colleges impact on the lives of these students and how do students believe the public FET colleges can and should impact on their lives?

\subsection{The Methodology}

To address these questions, in-depth interviews of approximately two hours were undertaken with 20 FET college students and graduates enrolled (or previously enrolled) at a public South African FET college located in Cape Town. The study did not attempt to achieve representivity in terms of students, programme or institutional type. Rather, it drew on as wide a cross section of students and graduates enrolled (or previously enrolled) across ten different FET programmes at the FET college3. The twenty interviews included five learners who were in the first six months of their study, seven in the six months prior to graduation and eight graduates.

The students were asked, as one aspect of the interview, to describe the benefits to their life of attending the FET college. Their response forms the empirical base for this paper. The positive bias inherent in the question suggests a bias towards the positive in the reporting. While this is undoubtedly the case, it is also true that most of the students (65\%) regarded FET as an affirming and positive experience. When asked if they would recommend the college to a younger sibling or friend, responses were positive and when asked if they would repeat the process of coming to the college if they were able to turn back the clock, again they responded predominantly in the affirmative. For most of the students involved in the study, FET was a positive and life changing experience. This is not to suggest that the FET colleges are in any way perfect and that the policy goals associated therewith have been achieved. It is however to highlight, and at this early juncture in the paper, that the idea put forward by Foster (1965a and b), Psacharopoulos (1991) and Oketch (2007) that students would prefer to avoid VET is no longer true in the case of all South African FET students.

Other aspects discussed in the interview and which are not shared in detail in this paper include the weaknesses of the college, areas in which they would like to see

\footnotetext{
2 Powell and Hall (2004) provide enrolments for South African public FET colleges as 406,144 in 2002.

3 The majority of the learners were enrolled for the National Certificate Vocational (NCV) or the Nated programmes (N-programmes). Learners enrolled for learnerships and skills programmes were, with the exception of one participant, not included in the study. A description of the different programmes can be found in Young and Gambol (2006).
} 
Forthcoming in the International Journal Of Educational Development, Vol. 32 (5).

improvement and aspects where the college could, with improvement, make a greater impact on students' lives. Aspects of these are addressed by the situational analyses undertaken by the Jaff (2000a-d) and by Kraak and Hall (1999).

The next section discusses the capabilities approach and how it is applied in the paper. This is followed by the central section of the paper which presents the findings of the student interviews.

\section{The capabilities approach}

The theoretical framework for this paper draws from the human capabilities approach. Developed by economist Amartya Sen and further developed by philosopher Martha Nussbaum the capabilities approach provides a comprehensive framework for conceptualising the quality of life and well-being of individuals.

Two central concepts in the capabilities approach are capabilities and functionings where capabilities comprise the opportunities available to a person to live a flourishing life or, stated differently, "what a person is able to do or be" (Sen, 2005: p.153) and functionings represent what a person actually does and the life that a person actually lives. The distinction between capabilities and functionings is between, "achievements on the one hand, and freedoms or valuable options from which one can choose on the other" (Robeyns, 2005: p.95).

\subsection{Applying the capabilities approach to VET}

An emerging body of literature has developed which applies the capabilities approach to the theorising of education which includes the work done by Arends-Kuenning and Amin, 2001; Bonvin and Galster, 2010; Lumby and Morrison, 2009; McCowan, 2011; Robeyns, 2005, 2006; Saito, 2003; Walker, 2005, 2006a and b, 2008, 2010; 2012; Walker et al, 2009; Walker and Unterhalter, 2007 and Unterhalter 2003, 2005. Despite the increasing application of the capabilities approach to schooling and higher education, the capabilities approach has until now not been applied to our understanding of VET.

This is unfortunate as the capabilities approach has a significant contribution to make to our thinking about VET. Its value lies in the paradigmatic shift that it makes from 'productivist' approaches that have traditionally existed as the dominant paradigm for VET policy and much of VET research (McGrath, 2012). Contrary to 'productivist' approaches which emphasise economic growth and income generation as key development objectives with human capital conceived as a means to that end, the capabilities approach emphasises human flourishing, with economic growth seen as a necessary but not sufficient means to achieve development. The purpose of 
Forthcoming in the International Journal Of Educational Development, Vol. 32 (5).

development in the capabilities approach is to expand the freedoms that human beings have to be and to do and the agency to choose these beings and doings. The emphasis is on removing the 'substantive unfreedoms' that hinder people from living a fulfilled life.

By putting the needs of people first - rather than the needs of the economy - the capability approach brings the discourse of social justice, human rights, and poverty alleviation to the forefront of our discussion of skills development and VET. Contrary to 'productivist' approaches to VET, which emphasise the working life of individuals through notions of human capital and employability, the commitment in the capabilities approach is to human flourishing which certainly includes what Bonvin and Galster (2010) describe as 'the capability for work', but is not limited to work. As Dreze and Sen (1995) argue, the "bettering of a human life does not have to be justified by showing that a person with a better life is also a better producer" (1995: p.184).

\subsection{Applying the capabilities approach to poverty alleviation}

In considering the value of a human life, we should be interested not only in the kind of life that an individual leads (that is, the functionings), but also in the freedom available to the individual to choose between different ways of living (Sen, 2009). Sen (2009) distinguishes between two overlapping aspects of freedom: the 'opportunity aspect' which is concerned with the opportunities available to people and the 'process aspect of freedom' which is concerned with agency and the processes of choice involved.

The distinction that Sen makes between the 'process aspect of freedom' and the 'opportunity aspect' of freedom is critical for understanding the contribution that the capabilities approach makes to human development and most particularly for our understanding of poverty. In the capabilities approach poverty is viewed as a multidimensional phenomenon existing as deprivation across multiple dimensions. These deprivations are affected by the opportunity aspect of freedom, through constrained opportunities to achieve and by the process aspect of freedom, through constrained opportunities for agency and choice (Alkire, 2005; Leßmann, 2011). The Multidimensional Poverty Index (MPI) makes the important contribution of going beyond standard measures of income to include the multiple deprivations that poor people face with respect to health, living standards and education. It is noteworthy that the MPI indicators focus on basic education and exclude reference to skills development as an aspect of the poverty index (McGrath, 2012). Nonetheless, while debate has raged over the measures selected and the respective weights applied and also on whether the MPI should consist of a composite indicator or a number of 
Forthcoming in the International Journal Of Educational Development, Vol. 32 (5).

individual measures, the consensus is that the multidimensionality of poverty is critical for understanding and addressing poverty.

Leßmann (2011), distinguishing between the 'opportunity aspect of freedom' and the 'process aspect of freedom' (Sen, 2009), argues that social policy tends to focus on enhancing the 'opportunity aspect of freedom' and tends to neglect the ability to choose or 'enhancing the capability to choose'. Concentrating on 'the capability to choose', she argues, is a fundamental and necessary condition for poverty reduction. The 'capability to choose' exists as what Nussbaum (2000) calls an internal capability', which is a capability that "develop[s] only with support from the surrounding environment, as when one learns to play with others, to love [and] to exercise political choice" (2000: p.84). As a learnt capability it requires support and teaching from others for it to develop. Leßmann (2009) suggests that a critical role for education in poverty alleviation is to develop this 'capability to choose'.

Her argument is supported and deepened by Appadurai (2004). Drawing on the experience of the Slum/Shack Dwellers International in Mumbai, he introduces the notion of aspiration to the topic. He notes that, "aspirations certainly have something to do with wants, preferences, choices and calculations" (2004: p.68). These 'wants', he argues, or 'aspirations' to use Appadurai's language, "often lie beneath the surface and are presented and understood as individual and disconnected desires for "this piece of land or that, for that marriage connection or another" (Appadurai, 2004: p.68). The reality though is far different. Aspirations are integrally connected to imbedded social and cultural notions of what constitutes the good in a society. They are unevenly distributed with the rich and the powerful having a more developed 'capacity to aspire' (Appadurai, 2004) than "poorer members, [who] precisely because of their lack of opportunities ... have a more brittle horizon of aspirations" (Appadurai, 2004: p.69).

The space of this paper disallows a detailed discussion of the nuanced and important differences between Appadurai's 'capacity to aspire' and Leßmann's 'capability to choose' which rests on differences in emphasis on agency and structure. Despite this difference, both are centrally concerned with human agency and both are concerned with the opportunity and ability of individuals and communities to affect their own lives. For the 'capability to choose' the focus is on the ability to choose from an array of possible opportunities. This is similarly so for the 'capacity to aspire', except that Appadurai emphasises the 'future-orientated logic' of aspiration by highlighting the ability of individuals and communities to imagine (conceptualise) and create (through either individual or group agency) an array of future opportunities that do not currently exist for them. 
Forthcoming in the International Journal Of Educational Development, Vol. 32 (5).

In the language of the capabilities approach, the term the 'capability to aspire' is applied in this paper. The term draws on Leßmann (2011) and Appadurai's (2004) joint concern with human agency in selecting from available opportunities and on Appadurai's notion of the ability to conceive of and then create an imagined and hoped for future which contains an array of opportunities currently or seemingly not available.

The question for VET would be on the extent to which VET is expanding the freedom of individuals through either the 'opportunity aspect of freedom' by expanding the array of possible opportunities to choose from and/or through the 'process aspect of freedom' by developing the capability to aspire.

\subsection{How is it applied in this study?}

The capabilities approach goes beyond providing a theoretical and abstract notion of social justice and human development, but provides a practical approach by which social justice can be enacted and monitored (Walker, 2005). The implication of the capabilities approach for educational evaluation is that it shifts the focus from normative and instrumental measures to an approach which evaluates educational policies and institutions by determining the implications of the policies and institutions for improving the lives of individuals (Walker, 2006a).

Three standard measures are applied to the evaluation of VET. First are measures of institutional efficiency and effectiveness determined through academic efficiency indicators such as pass rates and throughput rates, resource efficiency through indicators such as unit learner costs and lecturer to student ratios, and participation through Gross and Net Participation Rates (see Powell and Hall, 2000, 2002 and 2004 on South African FET colleges). Second are measures of graduate employment determined through graduate destination studies (cf. Cosser et al., 2003, Curtis, 2008, Powell, 2007). Third are measures of employer and student intention and satisfaction (see NCVER 2011a and b).

Each of these approaches is informative and necessary for VET policy and practice. However, individually and collectively, they are unable to identify the capabilities that are of value to students and furthermore, the extent to which VET is expanding or contracting these capabilities. If the purpose of education is to improve the lives of students, then it is this that should be evaluated. As argued by Sen (1999), "if freedom is what development advances, then there is a major argument for concentrating on the overarching objective, rather than on a particular means, or some chosen list of instruments" (1999: p.3) ascribed to achieve such.

This is not to undermine the importance of these standard evaluation measures. It is however to suggest that there may be capabilities - other than and in addition to the 
Forthcoming in the International Journal Of Educational Development, Vol. 32 (5).

capability to work - which may be of value to students. By adopting the approach utilised by Alkire (2002) for evaluating a poverty alleviation project in Pakistan in which she focussed on determining the "valuable' capabilities [which] a development activity had expanded or contracted" (Alkire, 2002: p6), the focus shifts from systemic and institutional efficiency to a focus on the extent to which these systems and institutions (efficient or inefficient, as they might be) expand or contract capabilities that students value. Following Alkire (2002), the study focussed on identifying from the perspective of students the capabilities that they consider valuable for their lives. As Alkire notes, "opportunities that people have reason to find horrid, or irrelevant, or cumbersome are not to be expanded" and opportunities that are valuable to people should be expanded (Alkire, 2005: p.3). Here the point is not that the perspective of students' should be the sole and only driver of FET policy. It is to stress the importance of targeting FET policy towards the well-being of students rather than, as is all too often the case, towards the best interest of the economy.

It is important to note that this paper does not evaluate the effectiveness of the capabilities approach as a developmental or educational approach or the theoretical and practical challenges inherent in the implementation of the capabilities approach. These debates are well provided elsewhere. Alkire (2002), for example, provides a useful summary of these debates related to development and Walker (2008) provides a critique of the silences in the capabilities approach around issues of power in education. Nor does the paper seek to determine mechanisms by which the theoretical frame of the capabilities approach can be applied to systemic or institutional evaluations of VET or to the development of VET policies and practice. While it is my contention that both aspects could benefit from the application of the capabilities approach and that the preliminary work undertaken in this study contributes thereto, the purpose of bringing the capabilities approach to the debate, together with an indication from students of what matters to them, is to broaden and open further the discussion of the role that VET can play in developing contexts.

\section{The Case study}

At twenty-something Allan (all names are pseudonyms) is older than most of his classmates. He is enrolled for the National Certificate Vocational (NCV) level 4 Electricity. This means that he has already spent two years at the college completing his NCV2 and NCV3 and that he will be writing his final NCV4 examinations at the end of the year. His final examinations are to be followed by 18 months of workplace 
Forthcoming in the International Journal Of Educational Development, Vol. 32 (5).

experience which will complete his $\mathrm{NCV}^{4}$ qualification in Electricity and will also prepare him for his trade test.

Allan left school at Grade 9 and completed his matriculation as a part-time student while working full-time. Contrary to the findings of Middleton, Ziderman and Adams(1993) who found that youth did not aspire to VET, the opportunity to study at the college is a dream come true for Allan. Living in his early years in what Lemanski (2009) describes as the then "virtually derelict" area of Westlake occupied by people "squatting in the non-serviced informal settlement" and those living in the housing for homeless people (2009: p.10), he regularly travelled past the college and decided then that "[he was] going to come to this college" one day.

Most of the students included in the study come from similarly disadvantaged socioeconomic communities. This is understandable as the college selected for the study, besides being one of best in the country in terms of student pass rates, is also one of the poorest urban colleges in the Western Cape in that it draws many of its students from some of the poorest socio-economic nodes in Cape Town, South Africa.

The college has five campus sites. Its smallest is located in Mitchells Plain, a Coloured area established in 1970 to provide housing for Coloured communities who were forcefully relocated in terms of South Africa's apartheid government's Group Areas Act. The area houses over 400000 people living in approximately $100 \mathrm{~km}^{2}$ with about 20\% living in informal housing (shacks), close to half living below the poverty line, 43\% unemployed and almost 40\% of the people aged 5 to 24 years are not attending school (Yu and Nieftagodien, 2008). The Khayelitsha campus is located in a township which was established by the apartheid government in the 1980 s to provide housing for 'legal' black residents in Cape Town5. Khayelitsha contains about a third of Cape Town's population, approximately 600 ooo people, in $52 \mathrm{~km}^{2}$ and is growing daily as people travel into Cape Town from the Eastern Cape and other rural areas. Khayelitsha contains a combination of low cost formal housing and informal housing. Over $71 \%$ live below the poverty line and $7 \%$ have no formal education. About a quarter of the households in Khayelitsha have no electricity, 17\% are without piped water and $5 \%$ are without waste removal (Department of Provincial and Local Government, 2006).

The three other campus sites, although located in relatively affluent historically white areas, draw their student population from Mitchells Plain, Khayelitsha and other low

\footnotetext{
${ }^{4}$ A description of the different programmes can be found in Young and Gambol (2006).

${ }^{5}$ The term 'legal' refers to residents who were provided a 'pass' under the apartheid regime's Pass Laws which provided 'legal' permission to live and work in Cape Town.
} 
Forthcoming in the International Journal Of Educational Development, Vol. 32 (5).

socio-economic areas including Lavender Hill, Retreat and informal settlements such as Vrygrond and Imizamo Yethu. Travelling in from socio-economically deprived areas to campus sites in affluent historically white areas takes its toll on students in terms of travel time (which for some is as much as four hours a day) and travel cost.

Alfred, a NCV4 hospitality student, while proudly sharing the support that his mother provides his studies and the challenges that it takes to provide even this support, discusses the cost of transport and the implications for his travel to college.

... my mom... with that little money she earns, still every month she puts my travelling aside. If there is, there is. If there isn't, then I must walk to here. But I don't find a problem because this is what I want to do and I want to achieve my goal that I've set for me in life.

While pockets of these areas are stable and peaceful, there are many pockets of these areas that are characterized by high levels of gangsterism and drug and alcohol abuse. The students who come from these areas traverse daily the dangers in their areas when travelling to college and bring with them the stress of their home lives and the pressures of the communities in which they live.

\subsection{Colleges of Choice - "It's so much more than just staying in the location"}

Allan's decision to study at the college was triggered by his experience in a big company that he worked in prior to enrolling at the college. He worked as a senior technician but did not earn the salary to match the work that he was doing and neither did he enjoy the status or the rank for the work. After three years at the company and having enjoyed one salary notch and status progression in that time he realised that "it [was] either working for this company for the rest of [my] life, slowly growing or [leaving and going to study and] growing at a decent pace".

Allan speaks with pride about being at the college and with pride at the trade that the college is preparing him for. When speaking about how he feels when he tells people that he is a FET student he says simply, and with a bashful shrug and a smile, that "it's basically telling them that I'm an electrician". His pride at being at the college is shared by Sonwabile, a young, female NCV4 Motor Mechanic student. Talking about how she feels about being an FET student, she says, "I am proud of the FET college ... because it's so much more than just staying in the location".

This pride is not limited to the learners alone, but is fully shared by their families. Wesley, a Professional Cookery student, shares the pride that his mother has in his status as a FET student enrolled for Professional Cookery.

She actually went to the neighbours one day and she gave them some [a sample of the food that the students' prepare at college]. Like, as in, 'just taste, my son did this'. And sometimes I hear she's on the phone with my aunty them, like bragging over the phone. Then I said, 'Why 
Forthcoming in the International Journal Of Educational Development, Vol. 32 (5).

do you do it? I'm not even finished yet with this stuff. I'm only starting now'. And she's like, 'It's nothing [that you're only starting]. I want to. I can. So why not?'

One reason for this pride is that they are moving beyond their parents qualifications. Sharon, a NCV2 Business Management student, explains that her parents "never had the opportunity to go and study" and therefore are always urging her to study in order that she might have "a better future". Sharon is not the only student who is moving beyond her parents' qualifications. Cosser et al. (2003) shows that the vast majority of FET learners come from disadvantaged families with few having parents qualified beyond secondary education and many having never completed primary school. These learners enter FET with no familial reference point to guide or support them. In fact, short of three students, all the students have gone beyond the qualifications of their parents and in many cases also their siblings. Allan, having completed his first two years of his NCV is "the first one out of the lot who is studying, [from] either side, from my mom's family and my dad's family". And Daphne explains that she is "the first one of my family that went further than Grade 12 ".

Another is the love that some of the students expressed for the trade that they are studying. Allan's decision to study as an electrician was shaped by his experience with electrical work. He "started to love it [electrical work]" and continued to work as an electrician in a full-time capacity while working for a big company and in a parttime capacity over weekends and after college whilst a student. He regards himself as having a special talent for fixing things which is recognised and acknowledged by the people in his family.

I love messing with electrical equipment ... anything that I can fix, I fixed. I try to. I still do it at home. My aunt or my mom them bring something and only if I can't fix it then they declare it broken.

Sonwabile, having never pictured herself as a motor mechanic is surprised by how much she is enjoying it. She claims that, "I'm living with it. It's in my veins. I love it". While describing how she feels about a professional position, she screws up her face to show her disgust of her mental image of a life of sitting at a desk working. "No", she says, "I don't see myself as a business lady sitting at a desk", rather Sonwabile "want[s] to do things with [her] hands, fix things".

Lubabalo has made a conscious choice to work with his hands. Driven by his religious and spiritual views his wish is to work close to the raw materials of the earth. His preference is to work with wood and as a second option metal which is why he is enrolled as a fitter and turner.

I must undergo some training in what I enjoy doing which is working with my hands. ... People want to sit behind a desk and do this and press that and answer the phone. That's what 
Forthcoming in the International Journal Of Educational Development, Vol. 32 (5).

people want. No one wants to build the building to work in, or make the table to work on. All those things, people don't want to do. So that's why I'm sure I'll forever have a place [a job or work].

Another reason is the belief, shared by many of the respondents, that the combination of the theory and practice provided by the FET colleges will give them an advantage in the labour market. Thulani, a N4 Business Studies student, indicates that he chose to attend the FET college despite achieving the grades required to attend university because he felt that the college would provide a better grounding for gaining employment.

I did not want to choose university because they focus mainly on academics and then FET College focuses both on academics and on practicals. So you'll have the time for practicals and you have the time for theory. So it's a good thing, even for your future because it's easier for you to get jobs and employment and things - you gain experience.

3.3. Constrained Choices - "I didn't want to be a motor mechanic from the first place"

Not everyone enrolled at the college has chosen to be at the college. Carol, a NCV4 Information Technology student, indicates that she would prefer to be studying at a local university of technology. She has gone as far as applying and twice she was accepted and on both occasions her parents were unable to afford the fees.

While Carol speaks openly about the financial constraint that has made it impossible for her to attend university and this even though she has achieved the grades and was twice offered a place, many of the other students do not speak so openly of the structural limitations that framed their choice. Instead, they have adapted their preferences to that of being an FET student. Thulani, for example, speaks passionately about the benefits of college as compared to university, but he never speaks directly of the financial limitations that must certainly have shaped his decision to enrol at the college. It would be dismissive of his opinion to deny that he selected the college for reasons other than what he claims, but it is clear from aspects of his conversation that his family is cash strapped and that the additional travel costs and university fees would have placed a burden on his mother who is raising both Thulani and his little sister on her own. It is also clear that Thulani's second responsibility, that of taking his younger sister to school and fetching her in the afternoons would have been very difficult if he had elected to take the university option.

Allan too talks about his 'love' for electrical work, but at the same he compares it to mechanical work which appears from his discussion to be the other option that was available to him at the time and decides that he prefers electrical to engineering. "My 
Forthcoming in the International Journal Of Educational Development, Vol. 32 (5).

dad's a mechanic", he says, "I've worked with him before and I didn't like it at all. I didn't like the mess of everything".

Sonwabile did not make the decision to attend the college. The decision was made by an aunt with whom she was staying at the time. Her aunt decided that it would be best for Sonwabile to leave school and attend the college. The decision was based on the difficulty of getting Sonwabile safely to and from school. Sonwabile describes missing a school test due to a taxi strike and the stress that this caused her (and in all likelihood her aunt as well). The benefit of the college to Sonwabile is that she walks to college. As she says, "I don't have to use taxi fare, I do not use taxi or bus or train, any travelling. I walk with my own two bare feet." Interestingly, and like Allan, when expressing her joy at being at the college she does so against the backdrop of the school that she was attending prior to the college, "I love it [the college]. So now I like this one. I don't like [the school]. It was even a corrupt school".

A theme underlying the stories of these students is the structural constraints within which they live and make choices. Where they live, the financial resources available for study and travel and the schools that they come from are all factors that have shaped their lives. But these students are different to Paul Willis' lads (Willis, 1977). Unlike Willis' 'lads' who were constrained by the structure to the extent that they had little belief in education as a tool for social mobility, these students have not rejected education and hierarchy. And, contrary to Paul Willis' lads are not focussed on "having a laff" (1977: p.14).

They are different to how they are presented in policy texts. In contrast to the faceless, two-dimensional learners presented in these texts, they are active participants who are involved in constructing learning careers and personal identities. This is not an attempt to argue away the social constructs embedded within the curriculum, location and structure of FET. It is an attempt to highlight the agency of these learners and the manner in which learners experience, participate and respond. For both Allan and Sonwabile, and perhaps Thulani too, the college is embraced as the best option within the social constructs of their lives.

So, while Paul Willis' lads reject "sitting in a classroom [and] sweating their bollocks off" (Willis, 1977, p.14), these students are sitting in the classroom, sweating their bollocks off and in some cases walking for many kilometres for the privilege of doing so. This is not to suggest that South African FET students are particularly diligent, but it is to highlight that overall the participants in the study saw their time at the FET college as an opportunity to be privileged, appreciated and respected. As stated by one of the graduates interviewed, 
Forthcoming in the International Journal Of Educational Development, Vol. 32 (5).

I wouldn't be who I am. I think I wouldn't be motivated to be who I am today because basically the people and the lecturers, they were awesome and they taught me who I am and taught me freedom of expression and freedom of, you know what I mean, be what you want to be ...

3.4. Changing Future Horizons - "From being a drop-out to ... [to] knowing what I'm capable of"

There is another reason why the college is embraced by these students. This is shaped not by the social constructs that shaped their past and with it their entry into the college, but by the role that the college has played in developing their futures, and the capability to aspire to futures that they had, until attending the college, not envisaged for themselves.

Allan did not expect to have done as well as he did at the college or, as he says, to "have made it this far". Contrary to previous learning experiences where he either did not cope or was just coping, Allan found his experience at the college to be an affirming one. He was coping well with his studies and due to the practical experience and theoretical understanding that he had gained working as an unqualified electrician was regarded by his lecturers and classmates as one of the better students in the class. Classmates, having identified his practical experience, frequently called on his help in practical classes. While he complained that "it frustrates me because I can't help them and help myself at the same time", he notes that the opportunity to support classmates has bolstered his confidence and made him recognize "how far ahead [of them] I actually am". He developed a practice of supporting his classmates by providing work experience opportunities for them. The experience of being at the college has affirmed him, developed his confidence in his own ability to learn and led him to rethink his future. Ideas of even further study, which prior to his enrolment at the college was not part of his agenda is now a concrete goal. Having spent much of his time supporting and 'teaching' other classmates he is now considering continuing to higher education with the idea of becoming a lecturer. This is markedly different to his initial idea which was to achieve his qualifications in order that he might work for himself in his own business.

I never thought that I will be studying further after I was working again and .. as I said I will [now] be studying further. I can also become a lecturer at the end. I can do many things with my life. It [being at the college] made me realise that I can go further in life.

Francois, a NCV4 graduate who returned to the college to do a semester of his $\mathrm{N}_{4}$ course, spoke of what the college meant to him. Francois came to the college after failing at school and struggling with and eventually managing to kick a drug habit. Needing a fresh start he enrolled at the college. His experience at the college 
Forthcoming in the International Journal Of Educational Development, Vol. 32 (5).

educationally and socially, together with being elected as the class representative on the Student Representative Council, bolstered his confidence in himself.

I've actually learnt a lot. I did learn a lot from the college, because when I came to the campus I knew barely anything. So, whatever I know today I've learnt from the college. And the reason why I'm working where I am now, is because of the college.

Mulhim, a NCV4 Finance, Accounting and Economics graduate, stays quite far from the college and travelled past another college to reach the college at which he studied. Mulhim is physically challenged and was forced to enrol at the college as it was the only college in the region that caters for physically challenged learners. The college has spent large amount of resources installing facilities that enable physically challenged students to move freely around the campus sites. It also funds an advisor who has the responsibility of working with and assisting these students to get around and cope with their studies. Mulhim, who is currently enrolled at a local university for an accounting degree, cannot be more positive about his experience at the college. For him, the college was a period of growth and development. As he says,

Basically they helped me find me. You know what I'm saying. That is the biggest contribution. They helped me find who I am. Not some loser that can't hook but some loser that likes challenges. Never backs down for anything. Not that they erased the loser part, the loser part is still there, but just never backing down, so that's the biggest contribution that they gave towards me.

Debbie is a final year NCV4 student studying Finance, Economics and Accounting. She left school at Grade 9. At the same time she left home and moved in with her boyfriend. She worked as a waitress for a few years before returning home and deciding that she had to study further. She describes this period as a dark period in her life in which she "had nothing, absolutely nothing". Debbie is also a very good mountain climber who has climbed as part of the South African national team. She balances her college work with mountain climbing competitions and providing mountain climbing lessons. When she first came to the college, she planned to complete the NCV programme which would provide her with a Grade 12 (or matriculation) equivalent and to proceed thereafter to university. After three years at the college she has come to the realisation that she no longer wants to study full-time at a university. While she plans to continue studying part-time she has decided and made concrete steps towards opening her own business. Together with her brother, they have had start-up funding approved and sponsorship committed by one of South Africa's biggest mountain climbing companies for the start-up of a mountain climbing school. She ascribes the idea of opening her own business and the success of completing business plans and securing funding to the content of her course.

I had like a whole plan, I was going to go to university, get my degree and now with this last year I've also opened my eyes up a lot. Especially what I've been studying now, especially when 
Forthcoming in the International Journal Of Educational Development, Vol. 32 (5).

you put everything into play at once it makes you realise that I don't want to go to university [full-time] anymore. I just want to start up my own business now because I know I can and with this course I know I've got the knowledge so I can definitely do it.

Debbie like many of the other students speaks of the way in which attending the college has changed her self-respect and the respect of her family for her. She describes the contribution of the college to her life as helping her shift "from being a drop-out to ... knowing what I'm capable of'. She describes her studying at the college as having shifted her relationship with her mother which historically had been a tense and awkward relationship, to a relationship of respect where, as she says,

Even just the way they approach me now, like my mother would speak to me on a different level, you know. She wouldn't speak to me like I don't know anything and she talks about me a lot as well. She brags about me now that I'm doing this course.

\section{Conclusion}

Five key messages emerge from the paper. The first topples the traditional view held of student attitudes to VET in Africa. It is clear from the pride and gratitude expressed at the opportunity to attend the college that the negative view of VET ascribed to students by Foster (1965a and b) and Psacharopoulos (1991) no longer serves to depict the views of all South African FET students and certainly is not true for the majority of the students included in this study. Nor do these students regard the FET college as anything remotely like 'mother's last hope' and 'last choice' for learners as the previous technical colleges were described by Malherbe (1977). In fact, according to a recent study undertaken by City and Guilds (2011), FET college students are "without exception extremely positive about their vocational programmes" (2011: p.10). Outside of the space of this study, but pertinent to the debate, would be further research on why this is the case.

Second is that the majority of the students included in this study do not perceive FET as terminal in nature and in most cases do not perceive themselves as, and to revert again to Malherbe, "the boy or girl whose ... abilities justify ... a vocational bias" (Malherbe, 1977: p.173). The majority (70\%) hoped to enrol in higher education on graduation and saw as their main obstacle the cost of higher education rather than their own intelligence, with a few of the students interviewed for the study already enrolled in and succeeding at higher education programmes.

For VET to suit the needs of these students, clear (and visible) progression pathways into higher education are a requirement. An area of concern is that articulation between FET and universities is uneven and unclear. Both college students and college staff are uncertain about the university requirements that students are to 
Forthcoming in the International Journal Of Educational Development, Vol. 32 (5).

meet to gain acceptance into specific programmes at local universities. This resulted in a number of mis-pathways. One student, for example, spoke of leaving school after Grade 9 and electing to attend the college even though he had the option of continuing with school. Like Thulani, he was under the impression that the practical component available at the college would provide him with a better grounding for the higher education programme in Mechanical Engineering that he hoped to undertake at a local university. He was disappointed to discover on graduation that Applied Physics, a compulsory entrance requirement for Mechanical Engineering, was not included in his $\mathrm{NCV}^{6}$ programme. His experience raises the importance not only of clear articulation pathways, but of programmatic provision through subjects such as Pure Maths and Applied Physics which open rather than close doors to higher education7.

Third is that while students spoke of the skills and attitudes that prepare them for work and the qualifications required to continue into higher education, they spoke longer and with greater passion and emotion about the empowerment role played by the college in enabling respect, self-confidence and personal pride. These students do not reflect the two dimensional learners presented in policy texts. They are far more than the unemployed youth and the future worker preparing to meet and address critical skills shortages. They are concerned with relationships with family members and with members of their community, their spiritual development, their personal dignity and with the social and economic challenges faced by their families and other members of their community. For these students, colleges are not simply an opportunity to access the labour market; colleges are an opportunity to gain satisfying work in workplaces where they will be respected and where they can make a contribution. And it is not just for them that this education is important. Yes, for many of the respondents it is the role that their success plays in securing a sustainable livelihood - to be "healthy and wealthy enough" (NCV4 Electrical student) - but it is also the role that it plays in enabling them to support other members of their family and to contribute to their communities.

When I'm done, I'd like to put another one of my family members through college too and that's also one of my goals. Not just to be doing this for myself but to help someone. ... I'm not a greedy person I don't want everything in the world. But I want to know that I can bring to my

\footnotetext{
${ }^{6}$ A description of the different programmes can be found in Young and Gambol (2006).

7 The tension that colleges face between the need to increase pass rates and the need to provide students with the academic qualifications needed for higher education is pertinent here. An example is the provision of mathematics literacy rather than Pure Mathematics. In an attempt to increase pass rates and driven by the shortage of Pure Mathematics lecturers, many South African FET colleges provide Mathematics Literacy rather than Pure Mathematics. While this ensures higher success rates, it unfortunately also serves to exclude FET students on graduation from a large number of higher education programmes.
} 
Forthcoming in the International Journal Of Educational Development, Vol. 32 (5).

country or to my place of work, I can bring with me energy, I can bring with me ideas of how to change.

Fourth, and linked to the above, is that students reported their experience at the college as culminating in a new sense of who they could be and provided the impetus for them to dream new futures. For these students, coming as most do from poorer socio-economic communities, the opportunity to create a vision of a future for themselves that extends beyond the experience of their families and many of their community members (or beyond their cultural capital if you like) was equally important, if not more important, than the curriculum content that they engaged in. For these students, the role that the college played in expanding their capability to aspire was one of the interventions that they most valued.

The importance of the capability to aspire for poverty alleviation is highlighted by Appadurai (2004) in his discussion of the Slum/Shack Dwellers International (SDI) in Mumbai. In this discussion he shows how the SDI together with their alliances work to transform the conditions of poverty through empowering poor people to create a horizon of "credible hopes" within which "more concrete capabilities can be given meaning, substance and sustainability" (Appadurai, 2004: p.81). Drawing from the experience of the SDI he argues that "since the work of development and poverty reduction has everything to do with the future, it is evident that a deeper capacity to aspire can only strengthen the poor as partners in the battle against poverty" (Appadurai, 2004: p.82). It is equally evident then, both from the argument of Appadurai (2004) and the experiences shared by these students, that strengthening the capability to aspire is central to the role that education and training is to play in poverty alleviation.

The evidence presented in this paper should not be interpreted as an indication that the public FET colleges have achieved and surpassed the policy goals of the Skills Development Act. Rather, it implies that what goes on in these institutions and how these goings on affect students is of vital importance. The liberal/ vocational debate, regarded by Foster (1987) as an old soldier that never dies, continues to have relevance and pertinence here (see Lewis, 2009 and Winch, 2000). Equally important is institutional culture and the culture of teaching and learning (see Bloomer, 2001 and James and Biesta, 2007), the development of 'pro-poor professionalism' in teaching staff (Walker et al, 2009), vocational cultures (see Colley et al, 2003) and the skills, aptitudes and attitudes related to craftwork (see Sennet, 2008 and Rose, 2005). Linked to this is the importance of the hidden curriculum highlighted by Pieck (2011) in his reporting of the Mexican experience. He argues that VET short courses provided in rural Mexico, while open to all the criticisms of quality, efficiency and effectiveness frequently laid at the door of VET, have a benefit 
Forthcoming in the International Journal Of Educational Development, Vol. 32 (5).

that cannot be measured through utilitarian and instrumental measures of cost efficiency and programme impact. These benefits, he argues "go beyond the mere learning of a trade or skill" but also include "socialisation, empowerment, [and] the motivation to set up micro-businesses ...” (Pieck, 2011). His argument has validity and strong resonance with the experience of the students interviewed in this study.

Last, but not least, is the value of the capabilities approach for the study of VET. In this regard, the paper is a tentative walk into complex territory. It argues that the capabilities approach provides an approach for conceptualising and evaluating VET which differs in orientation from dominant productivist approaches. The capabilities approach does so by shifting the focal area of concentration from economic development to human development. By placing the wellbeing of VET students at the centre of our concern it shifts the lens from income generation and with it employability, to a lens on capability expansion which includes but is not limited to employability.

This shift in emphasis has implications for the study of VET. First, and as provided in the case of this study, the conceptual tools and methodological implications of the capabilities approach resulted in empirical evidence which questions the core assumptions of VET students as portrayed in VET literature over the past half century - see points one and two above. Second, the application of the capabilities approach raises important questions about the needs of VET students; the extent to which we are aware of what these needs are and the extent to which we are meeting them. Third, the theoretical framework of the capabilities approach, with its emphasis on the well-being of individuals, challenges researchers and policy makers to take seriously the implications of VET policy, practice and culture on the lived lives of VET students. In the context of students expressing needs broader than employability, the capabilities approach opens up a set of questions about the purpose of VET. In short, and in summary, the application of the capabilities approach suggests a paradigmatic shift which results in different questions being asked (questions related to human development rather than human resource development) and insists that students previously excluded are to be given voice in the answering of these questions.

The shift in emphasis also has implications for South African and international VET policy, both of which are targeted to employability. The underlying assumption of current policies is that an increase in income will result in a decrease in poverty. This is not an unreasonable assumption as employment exists as one of the basic needs of a human being and insufficient income is undeniably the foremost factor in poverty. It is however potentially flawed, as employment does not necessarily equate to a living wage or a sustainable income. The capabilities approach takes a different 
Forthcoming in the International Journal Of Educational Development, Vol. 32 (5).

approach. By shifting attention away from the strategies adopted and directing attention squarely on the objective of poverty alleviation it focuses on the extent to which the FET colleges are expanding or contracting the capabilities of students which includes the capability to work, but also other capabilities as we've seen highlighted by the students in this study.

In the quest set for this paper, of 'reimagin[ing] the purpose' of vocational education, the central argument is that VET has an important role to play in poverty alleviation, but only if located in a multi-dimensional view of poverty. In this perspective, poverty is defined not solely by income with its associated emphasis in VET on training for employability, but also, and importantly, bythe central capabilities required to live a fulfilled and meaningful life. These central capabilities include the capability to work, but also include other capabilities such as political participation, social engagement and the freedom to reflexively choose how to live one's life (cf Alkire, 2002; Nussbaum, 2000 and 2011; Robeyns, 2005; Walker 2006 and 2007). In this broader notion of poverty, the role that VET plays includes training for employability, but also includes the expansion of other important capabilities such as, and in the voice of a FET student interviewed in this study, 'the ability to dream', or in the language of the capabilities approach, the capability to aspire.

\section{Acknowledgements}

My gratitude goes to the principal, the staff and the students of False Bay College for the support given to this study.

A special thanks to my first supervisor, Professor Simon McGrath, for his support and his patient advice and to my second supervisor, Professor Melanie Walker, for her guidance on the capabilities approach.

My gratitude also to Professor Michel Carton and Professor Kenneth King for their review of the initial draft of this paper which was presented at the 11th UKFIET conference on Education and Development held at the University of Oxford, $13-15$ September 2011. 
Forthcoming in the International Journal Of Educational Development, Vol. 32 (5).

\section{References}

Akojee, S., McGrath S., Visser, M., (2007). Further Education and Training colleges. In Human Sciences Research Council, Human Resources Development Review 2008: Education, Employment and Skills in South Africa. HSRC. Pretoria.

Allais, S., 2003. The National Qualifications Framework in South Africa: A democratic project trapped in a neo-liberal paradigm. Journal of Education and Work (16), 305-324.

Alkire, S., 2002. Valuing freedoms: Sen's capability approach and poverty reduction. Oxford University Press. Oxford.

Alkire, S., 2005. Measuring the Freedom Aspects of Capabilities. Paper given to the American Economic Association Conference. Mimeo. Harvard University. Cambridge.

Appadurai, A., 2004. The Capacity to Aspire: Culture and the Terms of Recognition. In Rao, R., Walton, M.(Eds.), Culture and Public Action. Stanford University Press. Stanford.

Arends-Kuenning, M., Amin, S., 2001. Women's capabilities and the right to education in Bangladesh. International Journal of Politics, Culture, and Society. 15 (1), 125-142.

Badroodien, A., Kraak, A., 2006. Building FET College Responsiveness: The Role of Linkages and Programme Units. Human Sciences Research Council. Pretoria.

Bhorat, H., 2006. Youth unemployment and education in South Africa. Paper presented at the Harold Wolpe Seminar. Cape Town.

Bhorat, H., 2008. Skills Mismatch Crisis: Can We Stem the Tide? South African Journal of Social and Economic Policy. 183-191.

Bloomer, M., 2001. Young lives, learning and transformation: some theoretical considerations. Oxford Review of Education. 27 (3), 429-449.

Bonvin, J., Galster, D., 2010. Making them Employable or Capable?. In Otto, H., Holger, H. (Eds.), Education, Welfare and the Capabilities Approach. Barbara Budrich Publishers. Opladen \& Farmington Hills.

City and Guilds., 2011. Practical matters: What young people think about vocational education in England, South Africa and the Netherlands. City and Guilds, Centre for skills development. London. 
Forthcoming in the International Journal Of Educational Development, Vol. 32 (5).

Colley, H., Dames, D., Tedder, M., Diment, K., 2003. Learning as becoming in vocational education and training: class, gender and the role of vocational habitus. Journal of Education and Training. 55 (4), 471-496.

Cook-Sather, A., 2002. Authorizing students' perspectives: Toward trust, dialogue, and change in education. Educational Researcher, 31 (4), 3.

Cosser, M., 2003. Graduate Tracer Study. In Cosser, M., McGrath, S., Badroodien, A., Maja, B. (Eds.), Technical College Responsiveness: Learner Destinations and Labour Market Environment in South Africa. HSRC Press. Cape Town.

Cosser, M., McGrath, S., Badroodien, A., Maja, B. (Eds.), Technical College Responsiveness: Learner Destinations and Labour Market Environment in South Africa. HSRC Press. Cape Town.

Curtis, D., 2008. VET pathways taken by school leavers. Australian Council for Educational Research (ACER). Victoria.

Daniels, R., 2007. Skills Shortages in South Africa: A Literature Review. DPRU Working Paper 07/121. Development Policy Research Unit, University of Cape Town. Cape Town.

Department of Education, 2008. National Plan for Further Education and Training Colleges in South Africa. Department of Education. Pretoria.

Department of Provincial and Local Government (DPLG)., 2006. Preliminary impact assessment for the Khayelitsha Mitchells Plain urban renewal programme. DPLG. Cape Town.

Dreze, J., Sen, A., 1995. India, Economic Development and Social Opportunity. Oxford University Press. Oxford.

Fisher, G., Hall, G., Jaff, R., 1998. Knowledge and skills for the smart province: Report to the MEC for education. National Business Initiative, Johannesburg.

Fisher, G., Hall, G., Jaff, R., 1999. Further Education and Training: The challenge of change. A situational analysis of FET institutions in the Western Cape. National Business Initiative. Johannesburg.

Fisher, G., Jaff, R., Powell, L., \& Hall, G., 2003. Public further education and training colleges. In Human Sciences Research Council (Ed.), Human Resources Development Review: Education, Employment and Skills in South Africa. Human Sciences Research Council. Pretoria. 
Forthcoming in the International Journal Of Educational Development, Vol. 32 (5).

Foster, P., 1965a. The vocational school fallacy in development planning. In Anderson, C. and Bowman, M. (eds.) Education and Economic Development. Aldine. Chicago.

Foster, P., 1965b. Education and social change in Ghana. Routledge and Kegan Paul, London.

Foster, P., 1987. Technical/ Vocational education in the less developed countries. International Journal of Educational Development. 7 (2), 137-139.

and social change in Ghana. Routledge and Kegan Paul, London.

Jaff, R., 2000a. A Situational Analysis of FET institutions in the Eastern Cape. National Business Initiative. Johannesburg.

Jaff, R., 200ob. A Situational Analysis of FET institutions in the Free State. National Business Initiative. Johannesburg.

Jaff, R., 2000c. A Situational Analysis of FET institutions in Mpumalanga. National Business Initiative. Johannesburg.

Jaff, R., 200od. A Situational Analysis of FET institutions in North West Province. National Business Initiative. Johannesburg.

James, D., Biesta, G., Colley, H. 2007. Improving learning cultures in Further Education. Routledge, Taylor and Francis Group. London and New York.

King, K., McGrath, S., 1999. Enterprise in Africa: Between Poverty and Growth. Intermediate Technology Publications Ltd. London.

King, K., 2009. A Technical and Vocational Education and Training Strategy for UNESCO. A Background Paper.

http://www.unesco.org/new/fileadmin/MULTIMEDIA/HQ/ED/pdf/gmr2012-EDEFA-MRT-PI-06.pdf

King, K. 2011. Editorial: Now that TVET has the Floor - What is the Storyline? Norrag News. NN46, September 2011.

King, K., 2009. A Technical and Vocational Education and Training Strategy for UNESCO. A Background Paper.

http://www.unevoc.unesco.org/fileadmin/user upload/docs/A Technical and Vo cational Education and Training Strategy for UNESCO. Background Paper by Kenneth King.pdf 
Forthcoming in the International Journal Of Educational Development, Vol. 32 (5).

Kraak, A., 2007. Three paths to intermediate skilling. In Human Sciences Research Council (Eds.), Human Resources Development Review: Education, Employment and Skills in South Africa. Human Sciences Research. Pretoria.

Kraak, A., Hall, G., 1999. Transforming Further Education and Training in South Africa: A case study of technical colleges in Kwazulu-Natal. Human Sciences Research Council. Pretoria.

Lemanski, C., 2009. Spaces of Exclusivity or Connection? Linkages Between a Security Village and Its Poorer Neighbour in a Cape Town Master Plan Development. Isandla institute. Cape Town.

Leßmann, O., 2009. Capability and Learning to Choose. Studies in Philosophy and Education. 28, 449-460.

Leßmann, O., 2011. Freedom of Choice and Poverty Alleviation. Review of social Economy. Forthcoming.

Lewis, T., 2009. Towards Reclaiming the High Ground in the Discourse on Vocationalism in Developing Countries. International Journal of Educational Development. 29, 558-564.

Lumby,J., Morrison, M., 2009. Youth perspectives: schooling, capabilities frameworks and human rights. International Journal of Inclusive Education. 13 (6), $581-596$.

Malherbe, E.G., 1977. Education in South Africa. Volume II, 1923-1975. Juta. Cape Town.

McCowan, T., 2011. Human rights, capabilities and the normative basis of 'Education for All'. Theory and Research in Education. 9 (3), 283 -298.

McGrath, S., 2000. Coming in from the cold? Further education and training in South Africa. Compare 30 (1), 65-84.

McGrath, S., 2004. Reviewing the development of the South African further education and training college sector ten years after the end of Apartheid. Journal of Vocational Education and Training 56 (1), 133-153.

McGrath, S., 2010. Public Further Education and Training colleges under new departmental structures: What challenges remain for 2010 and beyond? Review of Education, Skills Development and Innovation, June. Human Sciences Research Council. Cape Town. 
Forthcoming in the International Journal Of Educational Development, Vol. 32 (5).

McGrath, S., 2011. Where to now for vocational education and training in Africa?. International Journal of Training Research. 9, 35-48.

McGrath, S., 2012. Vocational Education and Training for Development: a policy in need of a theory? International Journal of Educational Development. Forthcoming.

McGrath, S., Akoojee, S., 2007. Education and skills for development in South Africa: Reflections on the accelerated and shared growth initiative for South Africa. International Journal of Educational Development 27 (4), 421-434.

McGrath, S., Akoojee, S., 2009. Vocational education and training for sustainability in South Africa: The role of public and private provision. International Journal of Educational Development 29 (2), 149-156.

McGrath, S., Badroodien, A., Kraak, A., Unwin, L., (Eds.), 2004. Shifting Understandings of Skill. HSRC Press, Cape Town.

McGrath, S., Needham, S., Papier, J., Wedekind, V., Attwal, H., Calitz, M., \& Van Der Merwe, T., 2010. Employability in the College Sector: A Comparative Study of England and South Africa. British Council: Department for Business Innovation and Skills. London.

Middleton, J., Ziderman, A., \& Adams, A.V., 1993. Skills for Productivity: Vocational Education and Training in Developed Countries. Oxford University Press. New York.

National Centre for Vocational Education Research (NCVER), 2011a. Australian vocational education and training statistics: employers' use and views of the VET system 2011. NCVER. Adelaide.

National Centre for Vocational Education Research (NCVER), 2011b. Australian vocational education and training statistics: student intentions 2011. NCVER. Adelaide.

Nussbaum, M., 2000. Women and human development. Cambridge University Press. Cambridge.

Nussbaum, M., 2011. Creating Capabilities. The Human Development Approach. Harvard University Press. Cambridge.

Oketch, M., 2007. To Vocationalise or Not to Vocationalise? Perspectives on Current Trends and Issues in Technical and Vocational Education and Training (TVET) in Africa. International Journal of Educational Development. 27 (2), 220-234. 
Forthcoming in the International Journal Of Educational Development, Vol. 32 (5).

Palmer, R., 2007. Skills for Work?: From skills development to decent livelihoods in Ghana's rural informal economy. International Journal of Educational Development. 27, 397-420.

Pieck, E., 2011. Using a Different Lens to Look at Technical Training. Norrag News. NN46, September 2011.

Powell, L. 2007. A survey of the employment and learning pathways of learnership participants. Department of Labour. Pretoria.

http://www.labour.gov.za/downloads/documents/research-documents/partb.pdf

Powell, L., \& Hall, G., 200o. Quantitative Overview of South African Technical Colleges - 1998. Department of Education. Pretoria.

Powell, L., \& Hall, G. 2002. Quantitative Overview of the Further Education and Training colleges - A sector in transition. Department of Education. Pretoria.

Powell, L., \& Hall, G. 2004. Quantitative overview of the further education and training college sector: The new landscape. Department of Education. Pretoria..

Psacharopoulos, G. 1985. Returns to education: a further international update and implications. Journal of Human Resources. 20 (4), 583-604.

Psacharopoulos, G., 1991. Vocational Education Theory, VOCED 101: Including Hints for 'Vocational Planners'. 11 (3), 193-199.

Robeyns, I., 2005. The Capability Approach: A Theoretical Survey. Journal of Human Development. 6 (1), 93-114.

Robeyns, I., 2006. The Capability Approach in Practice. Journal of Political Philosophy. 14 (3), 351-376.

Robeyns, I., 2006. Three models of education: rights, capabilities and human capital. Theory and Research in Education. 4 (1), 69-84.

Rose, M., 2005. The mind at work: Valuing the intelligence of the American worker. Penguin Books. England.

Saito, M., 2003. Amartya Sen's Capability Approach to Education: A Critical Exploration. Journal of Philosophy of Education. 37 (1), 17-33.

Sen, A., 1999. Development as Freedom. Oxford University Press. Oxford.

Sen, A., 2005. Human Rights and Capabilities. Journal of Human Development and Capabilities. 6 (2), 151-166. 
Forthcoming in the International Journal Of Educational Development, Vol. 32 (5).

Sen, A., 2009. The idea of justice. Penguin Books. England.

Sennett, R., 2008. The Craftsman. Penguin Books. England.

Tikly, L., Barrett, A., 2011. Social Justice, Capabilities and the Quality of Education in Low Income Countries. International Journal of Educational Development. 31 (1), 314 .

Unterhalter, E., 2003. The Capabilities Approach and Gendered Education: An Examination of South African Complexities. Theory and Research in Education, 1, 1, 7 .

Unterhalter, E., 2005. Global Inequality, Capabilities, Social Justice: The Millennium Development Goal for Gender Equality in Education. International Journal of Educational Development. 25 (2), 111-22.

Walker, M., 2005. Amartya Sen's Capability Approach and Education. Educational Action Research. 13 (1), 103-110.

Walker, M., 2006a. Towards a Capability-Based Theory of Social Justice for Education Policy-Making. Journal of Education Policy. 21 (2), 163-185.

Walker, M., 2006b. Higher Education pedagogies: A capabilities approach. Open University Press. Buckingham.

Walker, M., 2008. A Human Capabilities Framework for evaluating Student Learning. Teaching in Higher Education. 13 (4), 477-487.

Walker, M., 2010. Capabilities and Socially Just Education for Vulnerable Youth. Paper presented at the Human Development, Education and Vulnerable Youth, Pavia, 28-29 May 2010.

Walker, M., 2012. A capital or capabilities education narrative in a world of staggering inequalities? International Journal of Educational Development. Forthcoming. Walker, M., McLean, M., Dison, A., Peppin-Vaughan, R., 2009. South African universities and human development: Towards a theorisation and operationalization of professional capabilities for poverty reduction. International Journal of Educational Development. 27, 565-572.

Walker, M., Unterhalter, E. (Eds.), 2007. Amartya Sen's Capability Approach and Social Justice in Education. Palgrave Macmillan. United Kingdom.

Willis, P., 1977. Learning to labour. How working class kids get working class jobs. Columbia University Press. New York. 
Forthcoming in the International Journal Of Educational Development, Vol. 32 (5).

Winch, C., 2000. Education, Work, and Social Capital: Towards a New Conception of Vocational Training. Routledge Falmer. London.

Young, M., Gamble, J. (Eds.), 2006. Knowledge, curriculum and qualifications for South African Further Education.

Yu, D., Nieftagodien, S., 2008. Poverty and migration: Evidence from Khayelitsha/ Mitchell's Plain area. A Southern Africa Labour and Development Research Unit Working Paper Number 11. SALDRU, University of Cape Town. Cape Town. 